Doi: $10.4274 /$ vhd. 07269

Viral Hepatitis Journal 2014; 20(2): 67-71

\title{
The Knowledge and Behavior of Hairdressers and Barbers on Blood-Borne Diseases
}

\author{
Kuaför ve Berberlerin Kan Yolu ile Bulașan Hastallklar Hakkında Bilgi ve Tutumları
}

\author{
Nazlım AKTUĞ DEMIR1, Servet KÖLGELIER2, Lütfi Saltuk DEMIR3, Serap ÖZÇIMEN4, \\ Ahmet Çağkan INKAYA5
}

${ }^{1}$ Selçuk Universty Faculty of Medicine, Department of Infectious Diseases, Konya, Turkey

${ }^{2}$ Adlyaman Universty Faculty of Medicine, Department of Infectious Diseases, Adiyaman, Turkey

${ }^{3}$ Necmettin Erbakan Universty, Meram Faculty of Medicine, Department of Public Health, Konya, Turkey

${ }^{4}$ Konya Numune Hospital, Clinic of Infectious Diseases, Konya, Turkey

${ }^{5}$ Hacettepe Üniversitesi Faculty of Medicine, Department of Infectious Diseases, Ankara, Turkey

\begin{abstract}
Objective: Our purpose was to investigate the level of knowledge of hairdressers, barbers, manicurists and pedicurists who could easily get infected with certain blood-borne pathogens such as human immunodeficiency virus (HIV) hepatitis B virus (HBV) and hepatitis $\mathrm{C}$ virus (HCV).

Materials and Methods: This study was conducted on 147 barbers/hairdressers in the Adiyaman Province. Questionnaires were completed by the participants before the seminar in the training program co-prepared by Adiyaman Provincial Directorate of Health and the Chamber of Artisans. Those questionnaires completed by the participants were prepared after literature reviews.

Results: Thirty-six participants gave the correct answer to the question which was if HIV + HBV + HCV are the blood-borne pathogens. $72.9 \%$ of the respondents stated that HBV infection is, $21.9 \%$ of the participants stated that HIV infection is a blood-borne disease. Regarding the question on the correct use of razor blades and razors, only 10 participants (6.8\%) said "I use a new one for each customer", which was the correct answer. 17.3\% of the barbers-hairdressers got injured within the preceding month, and $49 \%$ of them within the past one year with sharp objects, such as blades and razors that they used on their customers. $60.1 \%$ of them were vaccinated against $\mathrm{HBV}$, and $39.9 \%$ of them were not.

Conclusion: Barbers'/hairdressers' knowledge of the blood-borne pathogens is insufficient, and they do not pay adequate attention to protect their customers and themselves. (Viral Hepatitis Journal 2014; 20(2): 67-71)

Key words: Barbers, blood-borne diseases, knowledge
\end{abstract}

\begin{abstract}
ÖZET
Amaç: Human Immunodeficiency Virüs (HIV), Hepatitis B Virüs (HBV) ve Hepatitis C Virüs (HCV) gibi kan yolu ile bulaşan enfeksiyonlarla kolayca enfekte olabilen kuaförler, berberler, manikürcüler ve pedikürcülerin bu konudaki bilgi düzeylerini araştırmak.

Gereç ve Yöntemler: Çalışma Adıyaman ilinde 147 berber ve kuaför ile yapııdı. Adıyaman II Sağlık Müdürlüğü ve Sanatkarlar Odası́nın beraber hazılladığı eğitim programı kapsamındaki seminer öncesi katılımcılar tarafından anketler dolduruldu. Anketler literatürler gözden geçirildikten sonra oluşturuldu.

Bulgular: Otuz altı katılımcı HIV + HBV + HCV'nin kan yolu ile bulaşıı̆ı doğru cevabını verdiler. Katılımcıların \%72,9'u HBV'nin, \%21,9'u HIV'in kan yolu ile bulaştığını belirtti. Tıraş bıçaklarının ve usturanın doğru kullanımı ile ilgili soruya sadece 10 katılımcı $(\% 6,8)$ "Her bir müşteri için yenisini kullanııı" doğru cevabını verdi. Berber ve kuaförlerin \%17,3'ü bir önceki ay \%49'u son bir yıl içinde müşterilerine kullandıkları jilet ve ustura gibi keskin cisimlerle yaralandıklarını belirttiler. Katıtımcıların \%60,1'i iHBV'ye karşı aşıı iken \%39,9'u aşısız idi.

Sonuç: Berber ve kuaförlerin kan yolu ile geçen patojenlere karşı bilgi düzeyleri yetersizdir ve kendilerini ve müşterilerini korumak için gerekli önemi göstermemektedirler. (Viral Hepatit Dergisi 2014; 20(2): 67-71)

Anahtar Kelimeler: Berber, kan yolu ile bulaşan hastalıklar, bilgi düzeyi
\end{abstract}

\section{Introduction}

Hepatitis B virus (HBV) infection is a serious health problem. According to the World Health Organization (WHO) data, more than 2 billion people in the world have been infected with $\mathrm{HBV}$, and more than 350-400 million of them have chronic hepatitis $B(C H B)$. Every year, 320.000 people die from chronic hepatitis, cirrhosis and hepatocellular cancer due to HBV (1-3).

Hepatitis B is one of the most important diseases most likely to be transmitted via blood. Sexual, perinatal and horizontal routes are 
also possible ways of transmission. Infections that are not caused by parenteral, sexual or perinatal contact are defined as horizontal infections. Horizontal transmission is important in endemic regions like in our country. Sharing personal equipments and close contact with an infected person are thought to be responsible for horizontal transmission of HBV. Horizontal infection occurs when objects, such as toothbrushes, razors, scissors, and manicure-pedicure sets are shared by everyone at home, at barber shops and hairdressers (4-6).

Hepatitis $\mathrm{B}$ and $\mathrm{C}$ and HIV are transmitted through exposure to blood and blood components (7). Bleeding due to the habit of removing the cuticles of the finger and toes nails, without appropriate sterilization of instruments can be an important factor of contamination by hepatitis $B$ virus (HBV) and hepatitis $C$ virus $(\mathrm{HCV})(8)$. It is known that after manicure and pedicure procedures, the risk of HBV infection increases (9). There is also increased risk for HCV infection shown in two different case-control studies held on blood donors and hepatitis $C$ cases (9-11).

Despite rigorous attempts, underlying risk factor for HBV and $\mathrm{HCV}$ infections cannot be explained in 5\%-50\% of cases and remains to be elucidated. Furthermore, ignorant daily practices may predispose to transmission. It has been suggested that the most significant factor in infection occurrence was usually sharing of infected sharp objects (12).

Considering the HBV infection complications and its impact on quality of life, prevention of the disease is of great importance. In addition to vaccination, additional protective measures should be applied and paths of transmission of the virus must be eliminated. Occupational risks are the most significant factor that increasing risk of adult transmission of HBV. One of the occupational groups with high risk of spreading the disease is barbers. Especially, transmission can occur if razors, manicure and pedicure tools contaminated with blood and body fluids are used on other people without sterilizing them $(13,14)$.

There has been limited research on the knowledge of bloodborne diseases of barbers and hairdressers who could easily get infected by HBV, HCV and HIV. Our purpose was to determine their level of knowledge on these certain infections.

\section{Material and Methods}

This descriptive study was conducted on 147 barbers/ hairdressers in the Adıyaman Province in April 2010. Questionnaires that were prepared after literature reviews were completed by the participants before the training in the training program co-prepared by the Adıyaman Provincial Directorate of Health and the Chamber of Artisans. Barbers and hairdressers were officially invited to the meeting by the Chamber of Artisans. All invited colleagues attended the training program and responded to the questionnaire. The data was entered to the SPSS 16.0 package program. For data analyses, descriptive statistics were used. After the questionnaires were completed, an informative seminar was conducted on bloodborne pathogens and general hygienic measures.

\section{Results}

The demographic features of the participants are given in (Table 1).

Eighty-seven percent of the subjects stated that their job was risky in terms of blood-borne diseases, and $12.9 \%$ of them said that it was not risky. In response to the questions for evaluating the level of knowledge on blood-borne diseases related with their job, 31 participants reported having no idea. Thirty-six of them gave the correct answer to the question which was if $\mathrm{HIV}, \mathrm{HBV}$, and $\mathrm{HCV}$ are the blood-borne pathogens. $72.9 \%$ of the participants knew that HBV infection was a blood-borne disease, $24.4 \%$ of them knew that HCV infection was a blood-borne disease and $21.9 \%$ of them knew that HIV infection was a blood-borne disease.

Eighty-one participants reported using styptic pencils (to stop the bleeding), and $98.7 \%$ of them stated that they used single-use styptic pencils.

Twenty-six barbers-hairdressers got injured within preceding month, and $49 \%$ of them within the past year with sharp objects such as blades and razors that they used on their customers. Only $33.6 \%$ of the subjects had first aid cabinets in their workplace to treat injuries immediately. $60.1 \%$ of the participants were vaccinated against HBV, and $39.9 \%$ of them were not.

\begin{tabular}{|c|c|c|c|}
\hline & & $\begin{array}{l}\text { Men's barbers } \\
n=79\end{array}$ & $\begin{array}{l}\text { Ladies hairdressers } \\
n=68\end{array}$ \\
\hline Gender & $\begin{array}{l}\text { Male } \\
\text { Female }\end{array}$ & $\begin{array}{l}79(\% 100) \\
-\end{array}$ & $\begin{array}{l}12(\% 17.6) \\
56(82.4)\end{array}$ \\
\hline Educational status & $\begin{array}{l}\text { Elementary school graduates } \\
\text { Secondary school graduates } \\
\text { High school graduates } \\
\text { Universty graduates }\end{array}$ & $\begin{array}{l}19(\% 24.1) \\
35(\% 44.3) \\
23(\% 29.1) \\
2(\% 2.5)\end{array}$ & $\begin{array}{l}9(\% 13.2) \\
22(\% 32.4) \\
34(\% 50.0 \\
3(\% 4.4)\end{array}$ \\
\hline Social security & $\begin{array}{l}\text { Yes } \\
\text { No }\end{array}$ & $\begin{array}{l}37(\% 46.8) \\
42(\% 53.2)\end{array}$ & $\begin{array}{l}36(\% 52.9) \\
32(\% 47.1)\end{array}$ \\
\hline Professional position & $\begin{array}{l}\text { Master barbers } \\
\text { Qualified barbers } \\
\text { Apprentice barbers }\end{array}$ & $\begin{array}{l}64(\% 81.0) \\
15(\% 19.0) \\
-\end{array}$ & $\begin{array}{l}57(\% 83.8) \\
9(\% 13.2) \\
2(\% 2.9)\end{array}$ \\
\hline Age (year) & Average (Standard deviation) & $32.3 \pm 10.2$ & $30.9 \pm 7.0$ \\
\hline Work duration (year) & Average (Standard deviation) & $18.1 \pm 10.1$ & $12.4 \pm 6.0$ \\
\hline Average income & Average (Standard deviation) & $1129.1 \pm 1290.1$ & $1389.3 \pm 817.3$ \\
\hline
\end{tabular}


Assessment of participants knowledge on risky tools such as razor blades, manicure-pedicure sets, scissors, depilatory needles, combs and brushes and hairclips are given in (Table 2).

Seventy-nine point nine percent of the participants had a schedule to keep their workplace clean. Regarding the questions on how they cleaned their counters and floors, $40.8 \%$ stated that they did not do daily cleaning, and $59.1 \%$ of them stated that they did daily cleaning with detergent solution. $23.8 \%$ of the participants stated that they did daily cleaning, and also overall cleaning once a week using household bleach, and $8 \%$ of them stated that they did daily cleaning, and also overall cleaning once a month using household bleach.

Seventy-nine point six percent of the participants disposed of tools like razor blades and razors that were in contact with blood in the regular garbage, and $10.9 \%$ of them disposed of them in a separate waste container, and $8.8 \%$ of them disposed of them in medical waste containers.

Regarding the questions on what they did to protect themselves and their customers, $12.2 \%$ reported doing nothing, $-38.7 \%$ using protective gloves, - $65.3 \%$ - washing their hands, - 51.1\% using working clothes, - and $59.5 \%$ reported using protective masks.

The answers regarding on which procedures the participants used protective gloves, how frequent they washed their hands and which sterilization technique they used to avoid contamination in work places are given in (Table 3).

Regarding the question on the correct use of razor blades and razors, only 10 participants said "I use a new one for every customer", which was the correct answer. Fourty participants replied "I wipe them with cologne", and 8 participants replied "I wash them with detergent", and 17 participants replied "I boil them".

Table 2. Assesment of participants knowledge on risky tools

\begin{tabular}{|l|l|l|}
\hline & Yes (\%) & No (\%) \\
\hline Razor blades were risky & 75.5 & 24.5 \\
\hline Manicure-pedicure sets were risky & 44.2 & 55.8 \\
\hline Scissors were risky & 39.4 & 60.6 \\
\hline Depilatory needles were risky & 37.4 & 62.6 \\
\hline Combs and brushes were risky & 49.6 & 50.4 \\
\hline Hairclips were risky & 35.3 & 64.7 \\
\hline
\end{tabular}

Table 3. Applications of participants to avoid contamination in workplaces

\begin{tabular}{|l|l|l|}
\hline Application & $\mathbf{n = 1 4 7}$ & $\%$ \\
\hline Sterilization technique & & \\
Ultraviyole & 72 & 48.9 \\
Boiling method & 38 & 25.8 \\
Dry heat & 20 & 13.8 \\
Autoclave & 17 & 11.5 \\
\hline Personel protector & & \\
Never used gloves & 70 & 47.8 \\
Wore gloves during waxing & 35 & 23.8 \\
Wore gloves during depilation & 18 & 12.2 \\
Wore gloves every procedure & 29 & 19.4 \\
\hline Frequency of washing their hands & & \\
After every customer & 82 & 56 \\
When their hands got dirty & 35 & 24 \\
At the end of their working hours & 30 & 20 \\
\hline
\end{tabular}

Regarding the questions for assessing their knowledge on the use and cleaning of towels and working clothes, none of the participants stated that they used single-use towels and working clothes, and $23.8 \%$ reported using different materials for each customer and washing the materials with detergent solution after use. It was noteworthy that $23.1 \%$ of the participants reported using the same materials on all customers until the materials get dirty.

\section{Discussion}

Hairdressing is a profession based on skills training. This training is provided in our country by the Chamber of Hairdressers, Ministry of National Education, Public Training Centers, the Chambers of Merchant Craftsmen, and private institutions. In addition to these, apprenticeship is another way to learn the profession (13-15). Percentage of getting vocational training was determined to be $53.7 \%$ in a study by Şahin et al. and $21.8 \%$ in a study by Hıdıroğlu et al. and $52 \%$ in a study by Boztaş et al. $(1,16,17)$. In our study, the percentage of getting vocational training was determined to be $43.6 \%$. Furthermore, $40.3 \%$ of the participants stated that they were trained on blood-borne diseases.

Educational level of hairdressers and barbers is very important for understanding and considering blood-borne diseases. $45.5 \%$ of the participants of the study by Hıdıroğlu et al. and $54.3 \%$ of the participants of the study by Kişioğlu et al. were elementary school graduates $(16,18)$. In this study, $19 \%$ of the participants were elementary school graduates, - 38.8\% secondary school, - 38.8\% high school, - and $3.4 \%$ of them were university graduates.

Awareness and knowledge are important for protection from diseases. Hıdıroğlu et al. reported in their study that $96.4 \%$ of the hairdressers had heard of HBV (16). In a study by Janjua and Nizamy on barbers, $13 \%$ of the participants knew that HBV and $\mathrm{HCV}$ infections were disease of the liver and caused jaundice (19). This percentage was $50.4 \%$ in the study by Şahin et al.. A similar study conducted in Pakistan showed that $38 \%$ of the barbers heard of hepatitis $(13,20)$. In the study by Boztaş et al., most of the participants stated that their tools had risk of infection (17). In a study by Murtagh et al., knowledge of hepatitis $C$ and its transmission was poor, with $62 \%$ of respondents incorrectly identifying the prevalence of hepatitis $\mathrm{C}$ and respondents incorrectly identifying sneezing (28\%), kissing (46\%) and sharing coffee cups $(42 \%)$ as a modes of transmission. $80 \%$ of the procedures carried out by beauty therapists in one weeek were reported to have led to exposure to blood (21). Regarding the degree of knowledge and level of awareness about viral hepatitis routes of transmission and prevention, $72 \%$ of the participants in a study by Oliveira et al. did not know the transmission routes of hepatitis $B$ and $93 \%$ did not know how to prevent it. As to hepatitis C, 85\% knew how the transmission occurred and $95 \%$ did not know how to prevent it; the other $3 \%$ of the subjects had a sufficient knowledge (22). $87.1 \%$ of the barbers and hairdressers, who participated in our study, stated that their job was risky in terms blood-borne diseases, and $12.9 \%$ of them said that it was not risky. $72.9 \%$ of the participants knew that HBV was a blood-borne disease, but the percentage of those who knew that HCV and HIV were also a blood-borne disease was very low $(24.4 \%, 21.9 \%$, respectively).

The percentage of people working at barbershops and salons with objects that they use on their customers was reported to be 
$16.7 \%$ in the study by Boztaş et al., and $17.2 \%$ in a study by Önder et al. $(17,23)$. In the study by Hıdıroğlu et al., the percentage of employee injuries with manicure and pedicure tools once or more than once was $60.9 \%$ (16). $30 \%$ of the participants in the study by Boztaş et al. stated that they were injured by sharp objects at least once within the preceding month (17). This shows that 3 out of 10 hairdressers experienced risky contacts during the preceding month in terms of acquiring HIV, HCV and HBV. In our study, $17.3 \%$ of the barbers-hairdressers got injured within the past one month, and $49 \%$ of them within the past one year with sharp objects like blades and razors that they used on their customers. It was noteworthy in our study that only $33.6 \%$ of the subjects had first aid cabinets in their work places to manage injuries immediately. Upon those findings, we conclude that barbers are not aware of the seriousness of the risky contacts. They ignore their cuts with sharp objects which may lead to transmission of blood-borne pathogens.

The study by Boztaş et al. showed that only $19 \%$ of the subjects working at hairdressers and salons got the hepatitis $B$ vaccine (17). The study by Hidiroğlu et al. showed that $72.7 \%$ of the participants did not get vaccinated against HBV (16). The percentage of not getting vaccinated is $60 \%$ in Canada (14). In the study by Kişioğlu et al., which was conducted on male barbers, the percentage of not having gotten vaccinated was $86.2 \%$ (18). Our study showed that $60.1 \%$ of the participants in our study were vaccinated against $\mathrm{HBV}$ and $39.9 \%$ of them were not. The reason for this high percentage of vaccination was associated with the fact that the Adiyaman Provincial Directorate of Health conducted a scanning and vaccination program for hairdressers and barbers 3 years ago.

There are only a few studies on barbers' practise in preventing blood-borne diseases. The risk associated with this infection way is usually ignored $(14,16)$. According to the results of a study on the knowledge of HIV and approaches of manicure-pedicure and depilation staff working at hairdressers and salons in Ankara, it was determined that these people's knowledge was insufficient and they wanted to get educated on these issues; and also, their tools were inadequately sanitized and sterilized. It was also observed that hairdressers, who participated the training under the scope of a questionnaire on determination of needs, have insufficient knowledge of issues like sanitization, sterilization, washing hands and using protective gloves $(16,23,24)$. Likewise, our study has shown that knowledge of hairdressers and barbers on blood-borne diseases, protection ways, sterilization and sanitization of their tools was inadequate.

The knowledge and awareness of barbers and hairdressers on the transmission of AIDS, and hepatitis $B$ and $C$ are of great importance. There are some unsafe practices that may lead to infections due to blood-borne viruses, for example, negligence in using beauty instruments such as needles for tattooing and razors for shaving can make these tools important factors in transmission of the infection from one client to another $(25,26)$. The results of some studies consistent with our findings show that barbershop and salon staff and their customers are under serious risk $(16,23,24)$. In our study, regarding the questions on what they did to protect themselves and their customers, $12.2 \%$ of the participants reported doing nothing, $-38.7 \%$ - using protective gloves, - $65.3 \%$ washing their hands, $-51.1 \%$ using working clothes, and $59.5 \%$ of subjects reported using protective masks.
In the study by Boztaş et al., $71 \%$ of the participants stated that they washed their hands regularly after each customer, and this rate was $59.5 \%$ in a study conducted on 489 hairdresser and salon employees in 1999 in Ankara (17). In our study, 56\% of participants stated that they washed their hands after each customer, and 24\% reported washing hands when their hands get dirty, and $20 \%$ of the subjects stated that they washed their hands at the end of their working hours.

In the study by Boztaş et al., $58 \%$ of the participants used protective gloves, which are barriers against blood and body fluids, and are effective for protection against many diseases including acquired immunodeficiency syndrome (AIDS) and Hepatitis B (17). Percentage of using protective gloves is equal to the findings of other studies conducted in Ankara $(16,17)$. In our study, $47.8 \%$ of participants stated that they have never used gloves, - $23.8 \%$ wore gloves during waxing, - $12.2 \%$ wore gloves during depilation,- and $19.4 \%$ of participants reported wearing gloves during each procedure.

Today, the use of single-use materials is becoming widespread in modern salons (15). In a study conducted in Canada, it was stated that despite the warnings of manufacturers of such materials, salon employees use the manicure-pedicure tools more than once, and they mostly use isopropyl alcohol for sanitization (14). In our study, it was determined that most of the materials, other than styptic pencils and wax spatulas, were used more than once after sterilization, and no single-use materials were used. The most noteworthy finding of our questionnaires was that only 10 of the 78 men's barbers stated that they used single-use razor blades or razors and disposed of them after use.

In the study by Hıdıroğlu et al., although almost all the manicuristspedicurists who participated in the study stated that they used sanitization methods to prevent infections, it was found that their sanitization methods were actually not reliable, scientific or effective methods (16). In the study by Boztaş et al., it was determined that the cleansing methods used by manicurists-pedicurists for their tools were various, but only $10 \%$ used the right method (17). In the study by Hıdıroğlu et al., it was seen that most of the participants did not know correct sanitization methods like autoclave (16).

In our study, $2.6 \%$ of participants reported using different manicure-pedicure sets for each customer, - 54\% using sanitizer devices, - $24 \%$ soaking their tools in household bleach solution, and $8 \%$ of the participants stated that they boiled their tools. It was noteworthy that those, who used household bleach, used it improperly.

In the study by Boztaş et al., 33\% of the participants were performing depilation, and $97 \%$ of them stated that their customers had their own depilation needles, and their customers brought their needles with them (17). In our study, $27 \%$ of the participants said that they performed depilation, and the ratio of needle-depilation was $4 \%$, and every customer had their own needle. These percentages show that there is awareness of using different depilation needles for every customer. Different depilation needles used for each customer; same approach should be taken in manicure and pedicure: Different tools should be used for each customer. If separate tools cannot be purchased for every customer, then the customers should be asked to purchase their own tools for their health. In our study, $42 \%$ of participants stated that they performed manicure-pedicure, and the percentage of using a different set for each customer was $2.6 \%$. 
Tools, such as razor blades, razors and depilation needle tips which can be risky regarding blood-borne infections, should be disposed of in medical waste containers in order to prevent contamination. In our study, it was noteworthy that $79.6 \%$ of participants disposed of materials such as razors contaminated with blood in regular waste containers.

Consequently, when we consider our study and the literature, it is revealed that barbershop and salon employees behave inattentive during work, although they use risky tools that could be contaminated by blood-borne pathogens, and they are under risk of getting injured with their tools. This shows that their knowledge on the subject is insufficient or they do not pay adequate attention to protect their customers and themselves. We think that these professionals should be trained on vocational risks and they should be audited more frequently.

\section{Conflict of interest: None declared.}

\section{References}

1. Lavanchy D. Hepatitis B virus epidemiology, disease burden, treatment, and current and emerging prevention and control measures. J Viral Hepat.2004;11(2): 97-107.

2. Dienstag J. Hepatitis B virus infection. New England Journal of Medicine 2008; 359: 1486-500.

3. EASL Clinical Practice Guidelines: Management of chronic hepatitis B. Journal of Hepatology 2009; 50: 227-242.

4. Mıstık R, Balık I. Turkiye'de Viral Hepatitlerin Epidemiyolojik Analizi (Epidemiologic Analysis of Viral Hepatitis in Turkey). Balık I, Tekeli E, editors. Viral hepatit 2002 Kitabı. (cited 2005 July 04). Avaible from: URL: http://www.vhsd.org/dergiler.htm.

5. Taşyaran MA. HBV Infeksiyonu Epidemiyolojisi (Epidemiology of HBV Infection). In: Tekeli E, Balık I, editors. Viral Hepatit 2003. Viral hepatitle savaşım derneği 2003. p:121-28.

6. Robinson WS. Hepatitis B virus and Hepatitis D virus. In: Mandell GL, Bennett JE, Dolin R, editors. Principles and Practice of Infectious Diseases. New York: Churchill Livingstone; 1995. p. 1406-1439.

7. R Kordi, W A Wallace. Blood borne infections in sport: risks of transmission, methods of prevention, and recommendations for hepatitis B vaccination. Br J Sports Med 2004 38: 678-84.

8. Oliveira AC, Focaccia R. Survey of hepatitis B and C infection control: procedures at manicure and pedicure facilities in São Paulo, Brazil. Braz J Infect Dis. 2010 ; 14: 502-7.

9. Mele A, Corona R, Tosti ME, Palumbo F,Moiraghi A, Novaco F, et al. Beauty treatments and risk of parenterally transmitted hepatitis: results from the hepatitis surveillance system in Italy. Scand J Infect Dis 1995; 27: 441-444.

10. Karmochkine M, Carrat F, Dos Santos O, Cacoub P, Raquin G. A case-control study of risk factors for hepatitis $C$ infection in patients with unexplained routes of infection. J Viral Hepat 2006; 13: 775-782.
11. De Oliveira-Filho AB, Pimenta ASC, Rojas MFM, et al. Likely transmission of hepatitis $C$ virus through sharing of cutting and perforating instruments in blood donors in the State of Pará, Northern Brazil. Cad Saúde Pública 2010; 26: 837-844.

12. Oliveira AC, Focaccia R. Survey of hepatitis $B$ and $C$ infection control: procedures at manicure and pedicure facilities in São Paulo, Brazil. Braz J Infect Dis 2010; 14(5): 502-507.

13. Şahin NH, Bilgiç D, Esen Ü, Çetinkaya R, Tozoğlu Z. Bayan Kuaförü Çalışanlarının Hepatit B'ye Illişkin Bilgi ve Uygulamalarının Belirlenmesi. TAF Prev Med Bull 2009; 8(2): 147-154.

14. Johnson IL, Dwyer JJM, Rusen DI,Shahin R, Yaffe B. Survey of infection control procedures atmanicure and pedicure establishments in North York. Can J Publıc Health. 2001; 92(2): 134-137.

15. Kömürcü A. Kuaför Manikür Pedikür Makyaj ve Güzellik Çıraklık Eğitim Kitabı, Kuaförlük Meslek Bilgileri. Istanbul: Tor Ofset; 2005.

16. Hıdıroğlu S, Karavuş M, Topuzoğlu A, Şalva T. Manikür-pedikür yapan kadın berberlerin hepatit B hakkındaki bilgi tutum ve davranışları. TAF Prev Med Bull 2006; 5(4): 276-286.

17. Boztaş G, Çilingiroğlu N, Özvarıș ŞB, Karaöz A, Karataş F, Kara $\mathrm{G}$, et al. Ankara ilinin bir semti'nde bulunan kuaför ve güzellik salonlarında çalışan kişilerin kan yoluyla bulaşan hastalıklar konusunda bazı görüş ve uygulamaları. Hemşirelik Yüksekokulu Dergisi. 2006; 60-68.

18. Kişioğlu N, Öztürk M, Uskun E, Doğan M. Isparta'da Kuaför ve Güzellik Salonlarında çalışanların HIV/AIDS Konusunda Bilgi ve Tutumları. Hacettepe Üniversitesi HIV/AIDS Tedavisi Araştırma Merkezi, (Cited 2011 July 15). Available from : http://www. hatam.hacettepe.edu.tr/hatam714.shtml\#4.

19. Janjua NZ, Nizamy AM. Knowledge and Practices of Barbers about Hepatitis B and C Transmission in Rawalpindi and Islamabad. J Pak Med Assoc 2004; 54(3): 116-119.

20. Chaudhry MA, Rizvi F, Ashraf MZ, Niazi MAZ. Knowledge and practices of barbers regarding hepatitis $b$ and hepatitis $C$ in Bahra Kahu, Islamabad-Pakistan. RMJ 2010; 35(1): 37-40.

21. Murtagh MJ, Hepworth J. Hepatitis $C$ in the workplace: a survey of occupational health and safety knowledge and practice in the beauty therapy industry. Aust N Z J Public Health. 2004; 28(3): 207-11.

22. Oliveira AC, Focaccia R. Survey of hepatitis $B$ and $C$ infection control: procedures at manicure and pedicure facilities in São Paulo, Brazil. Braz J Infect Dis. 2010; 14(5): 502-7.

23. Onder OR, Sarp N. Ankara'da Kuafor ve Guzellik Salonlarında Manikur ve Pedikur Uygulayan Personelin HIVIAIDS Konusundaki Bilgi ve Tutumları. Sağlık ve Toplum. 1999; 2: 35-40.

24. Üner S, Özvarış SB. Kan Yoluyla Bulaşan Hastalıklardan Korunmada Farklı Bir Hedef Grup Için Eğitim Programı. Hacettepe Toplum Hekimliği Bülteni. 2001; 2: 22.

25. Ataei B, Shirani K, Alavian SM, Ataie M. Evaluation of Knowledge and Practice of Hairdressers in Women's Beauty Salons in Isfahan About Hepatitis B, Hepatitis C, and AIDS in 2010 and 2011. Hepat Mon. 2013; 13(3): 6215.

26. Kose $S$, Mandiracioglu A, Oral AM, Emek M, Gozaydin A, Kuzucu L,et al. Seroprevalence of hepatitis B and C viruses: awareness and safe practices of hairdressers in Izmir: a survey. Int J Occup Med Environ Health. 2011; 24(3): 275-82. 